Marquette University

e-Publications@Marquette

College of Nursing Faculty Research and

Publications

Nursing, College of

7-1-2013

Spirituality, Religiosity, Depression, Anxiety, and

Drug-Use Consequences During Methadone Maintenance Therapy

Linda B. Piacentine

Marquette University, linda.piacentine@marquette.edu

Accepted version. Western Journal of Nursing Research, Vol. 35, No. 6 (July 2013): 795-814. DOI. (C) 2013 SAGE Publications. Used with permission. 


\title{
Spirituality, Religiosity, Depression, Anxiety, and Drug-Use Consequences During Methadone Maintenance Therapy
}

\author{
Linda B. Piacentine \\ College of Nursing, Marquette University \\ Milwaukee, WI
}

\begin{abstract}
:
Substance addiction is damaging to the health of persons, families, and society. Often the person with addiction has decreased spirituality and religiosity and suffers from anxiety, depression, or both, increasing the risk for continued substance use and its concomitant negative consequences. The study purpose was to describe spirituality and religiosity, among persons enrolled in methadone maintenance therapy and to examine associations between spirituality, religiosity, anxiety, depression, and drug use consequences. Using a descriptive and cross-sectional correlational design, 108 participants completed questionnaires assessing the study variables. Spiritual well-being was similar to other addiction samples and lower than healthy person samples. Most participants described themselves as spiritual or religious though religious participation was lower than in their past. The analysis indicated that spirituality, religiosity, depression, anxiety, and negative drug use consequences are interrelated in the person with addiction. Higher anxiety was predictive of negative drug use consequences.
\end{abstract}

Keywords: Spirituality, religiosity, substance addiction, anxiety, depression

Approximately $12.1 \%$ of American adults used illicit drugs in 2010 with an estimated 6.1\% meeting Diagnostic and Statistical Manual of Mental Disorders (4th ed., American Psychiatric Association, 1994) criteria for sub- stance-use disorder (Substance Abuse and

Western Journal of Nursing Research, Vol. 35, No. 6 (July 2013): pg. 795-814. DOI. This article is @ SAGE Publications and permission has been granted for this version to appear in e-Publications@ Marquette. SAGE Publications does not grant permission for this article to be further copied/distributed or hosted elsewhere without the express permission from SAGE Publications. 
Mental Health Services Administration, 2012). Illicit drug-use costs in 2007 were above US\$193 billion when accounting for negative consequences on health, crime, and productivity (National Drug Intelligence Center, 2011). Especially concerning was the number of opioid analgesic poisoning deaths that more than tripled from 1999 to 2006 (Warner, Chen, \& Makuc, 2009). Opioid analgesics are not only damaging to health but may also provide a gateway to using other substances (Center for Substance Abuse Treatment [CSAT], 2005). Use of opioids can lead to addiction in which persons compulsively continue the use of sub- stances despite negative consequences to finances, health, families, and social life. These negative consequences of addiction complicate substance-use dis- order treatment (Conner, Ross, Baciewicz, Sworts, \& Meldrum, 2009). Successful treatment for opioid addiction is infrequent and treatment rates have not measurably improved for several decades despite increasing options for therapy to address addiction (Stimmel, 2009). Successful treatment of opioid addiction can be hampered by the common comorbidities of depression and anxiety (CSAT, 2005). An additional challenge is the often expressed social stigma of opioid addiction being a "self-inflicted condition resulting from a moral failing and that this condition is best handled as a criminal matter" (CSAT, 2005, p. 8). Methadone maintenance therapy (MMT), an opioid addiction therapy, is hampered by this social stigma and other factors such as medication side effects, restrictive clinic schedules for daily drug doses, and cost (White \& Mojer-Torres, 2010). The poor rates of successful treatment and the complexity of the person with opioid addiction warrant further research.

\section{Spirituality and Religiosity in Persons With Addiction}

To better understand addiction treatment, spirituality and religiosity are important factors to study (Miller \& Bogenschutz, 2007). Increased spirituality and religiosity have been found to be protective in persons using alcohol (Tonigan, 2007) and illicit drugs (Miller \& Bogenschutz, 2007). Among those entering addiction treatment, religious practices have been found to be low (Brizer, 1993). Alcoholics Anonymous (AA), which is infused with spirituality, has been a successful program for treating alcoholics (Miller \& Bogenschutz, 2007). After treatment, persons in recovery with higher spirituality 
have fewer relapses and longer term recoveries (Green, Fullilove, \& Fullilove, 1998). The studies investigating spirituality in those undergoing treatment or who are currently addicted to substances are few. Focus groups of patients in outpatient drug treatment noted that substance use leads to decreased spirituality and decreased religious practices (Heinz et al., 2010). In two clinical trials in an acute detoxification program, a spiritually directed intervention was found not to improve treatment outcomes of persons who were in treatment but not on maintenance therapy (Miller, Forcehimes, O'Leary, \& LaNoue, 2008). Evidence suggests that spirituality is associated with recovery, prevention of relapse, and improved mental health status (Miller \& Bogenschutz, 2007), but perhaps not better outcomes in acute treatment (Miller et al., 2008). It is not known if spirituality and religiosity are associated with a change in drug-use patterns or druguse consequences (Miller \& Bogenschutz, 2007).

Depression and anxiety are additional concerns complicating addiction treatment. Depression and anxiety have been studied among individuals in opiate treatment (Verthein, Degkwitz, Haasen, \& Krausz, 2005). In general, these studies have found that individuals undergoing treatment for illicit drug use with anxiety and/or depression are more likely to continue substance use and suffer the negative consequences of addiction. High levels of depression and anxiety along with low levels of spirituality have been found to be common in substance addiction (Darke, Swift, \& Hall, 1994; Ellison \& Smith, 1991; Miller \& Bogenschutz, 2007). No study has yet examined the relation- ships between spirituality, religiosity, anxiety, depression, continued drug use, and drug-use consequences among persons undergoing opiate treatment. Persons in MMT take a long-acting opioid in place of the drug to which they were addicted. Recently, MMT has been viewed not as detoxification, but rather a substitution therapy with the goal of long-term recovery, not abstinence (White \& MojerTorres, 2010). The results of this study will help with the development of more effective treatment for the complex person with addiction.

\section{Conceptual and Theoretical Perspectives}

Spirituality is a complex and highly personal concept that includes "elements of love; compassion; caring; transcendence; relationship with God; and the connection of body, mind, and spirit" (O’Brien, 2011, p.6). Traditionally, spirituality was a part of religion, 
but, more recently in Western culture, spirituality is seen as larger than religion, meaning that people may consider themselves spiritual even when not practicing a religion (Koenig, 2008). Spirituality is defined by individuals based on their own beliefs and it is difficult to measure (Koenig, 2009) However, better understanding of what spirituality means to a person's health can be gained by assessing spiritual well-being (SWB). SWB refers to a satisfaction with life that one experiences from having purpose and meaning in life and is experienced through transcendence or a relationship with God or a higher power. (Ellison, 1983; Ellison \& Smith, 1991). Understanding SWB will help in understanding how spirituality impacts the actions of the person with addiction.

Religiosity "relates to a person's beliefs and behaviors (practices) associated with a specific religious tradition or denomination (O'Brien, 2011, p. 5). Religious behaviors can include "support of a faith community, affirmation in worship, encouragement of spiritual companions, consolation from prayer, and communication with God through these religious practices" (O'Brien, 2011, pp. 98-99). Thus, religiosity describes participation in an "organized" religion or faith tradition.

The Neuman Systems Model provided a guiding framework for conceptualizing the addicted person as a complex system with multiple interacting components. The person is defined in the Neuman Systems Model as a dynamic system, a composite of five interacting variables: physiological, psychological, sociocultural, developmental, and spiritual (Neuman \& Fawcett, 2002). Table 1 presents the linkages between study concepts and measures. The person with addiction is affected in all these areas. This study focused on the spiritual dimension which Neuman conceptualizes as being born with a potential energy akin to a "seed" (Neuman \& Fawcett, 2002). This seed needs to be nurtured and allowed to grow and transform. In this study, spirituality was defined as "the innate capacity of the human person to transcend herself/himself to experience meaning and purpose in life through contemplation and action aimed ultimately toward the sacred" ( $\mathrm{J}$. Schaefer, personal communication, August 31, 2010). When a person acts against this innate aspect of spirituality, they are keeping from growing and transcending. Religiosity is the expression of the importance one gives to religious beliefs and practices (Fehring, Miller, 
NOT THE PUBLISHED VERSION; this is the author's final, peer-reviewed manuscript. The published version may be accessed by following the link in the citation at the bottom of the page.

\& Shaw, 1997). Religiosity was seen as a way to nurture a person's spirituality and to grow their spiritual "seed".

\section{Purpose}

The purpose of this study was to describe the spiritual wellbeing, religiosity, depression, anxiety, continued drug use, and drug use consequences among persons enrolled in methadone maintenance therapy (MMT). This study examined SWB in the person with addiction who was taking methadone under supervision in a MMT program. This purpose was addressed by answering three research questions:

Research Question One: What are the spiritual well-being and religiosity among persons enrolled in methadone maintenance therapy?

Research Question Two: Are spiritual well-being, religiosity, depression, anxiety and drug use consequences associated?

Research Question Three: Do spiritual well-being, religiosity, depression, and anxiety predict continued drug use and drug use consequences among persons enrolled in methadone maintenance therapy?

\section{Methods}

A descriptive and cross-sectional correlational design was used to answer the research questions. An a priori analysis estimated a necessary sample size of 108 based on the multiple regression for four predictor variables (spiritual well-being, religiosity, anxiety, depression) with a desired power of 0.90 , a medium effect size of 0.15 and a significance level of 0.05 and logistic regression with 0.90 power, $\mathrm{p}=0.05$, and an odds ratio of 2 (G-power 3.0, Faul, Erdfelder, Lang, \& Buchner, 2007).

A convenience sample of participants who were enrolled in MMT was recruited at a private, nonsectarian outpatient MMT clinic located in a large Midwestern city. The majority of the clinic patients were male $(61 \%)$, White (79\%), young adults (49\% less than 35 years old) with reportedly low incomes (58\% less than $\$ 15,000)$. Participants met the following study inclusion criteria: over the age of 18 , ability to speak, read, and understand English and to answer computerized questions independently. Exclusion criteria included persons who

Western Journal of Nursing Research, Vol. 35, No. 6 (July 2013): pg. 795-814. DOI. This article is @ SAGE Publications and permission has been granted for this version to appear in e-Publications@Marquette. SAGE Publications does not grant permission for this article to be further copied/distributed or hosted elsewhere without the express permission from SAGE Publications. 
ended treatment within the previous three months and were reenrolled in treatment for less than two weeks.

\section{Measures/Instruments}

Spiritual well-being, religiosity, anxiety, depression and drug use consequences were measured through self-administered questionnaires. The following demographic data were collected to describe the sample: age, race, ethnicity, education, time in treatment, religious history, illicit drugs used, and years of MMT.

Spritual well-being

The Spiritual Well-Being Scale (SWBS [Ellison, 1983]) is a 20item tool with two 10-item subscales. The Existential Well-Being (EWB) subscale explores a relationship with a higher being or God, and the Religious Well-Being (RWB) subscale explores a sense of meaning and purpose in life. Each item is scored on a six-point Likert-type scale using the anchor words: "strongly agree" and "strongly disagree". Higher scores indicate greater spiritual well-being. The strong psychometric properties of the SWBS have been demonstrated in various populations including a group likely similar to the MMT population, outpatient counselees (Bufford, Paloutzian, \& Ellison, 1991). Internal consistency has ranged from 0.82-0.94 for the total SWBS scale, 0.78-0.86 for the existential well-being (EWB) and 0.890.94 for the religious well-being (RWB) subscales (Hill \& Hood, 1999). The scale has been used in several studies of substance use disorders (Brome, Owens, Allen, \& Vevaina, 2000; Piderman, 2005; States, 2001).

Religiosity

The Religious Background and Behavior Questionnaire (RBB) is a 13-item tool developed to measure lifetime and recent religious behavior (Connors, et al., 1996; Hartz, 2005). The first question asks the person to self-identify as one of the following: atheist, agnostic, spiritual, religious or unsure. The remaining questions assess frequency of participation in various religious or spiritual activities in the last year and again in their lifetime ranging from never to more than once a day. Possible scores on the tool range from 0-46 with higher scores indicating greater religiosity. Connors, Tonigan, and Miller (1996) demonstrated good overall scale reliability $(a=0.86)$ in a 
large study of people with alcoholism. Two factors were identified with a five-item God Consciousness (GC) scale $(a=0.76)$ and an eight-item Formal Practices (FP) scale (0.81).

\section{Depression}

Depression was measured with the Patient Health Questionnaire 9-item depression module (PHQ-9; Kroenke, Spitzer, \& Williams, 2001). The nine items on the tool are rated on how often in the last two weeks the person has exhibited depression symptoms. The frequency of occurrence ranges from not at all to nearly every day. The highest score on the PHQ-9 is 27 with scores over 15 indicating a need for depression treatment. The tool has been validated in the substance use disorder population and has strong psychometric properties with high internal consistency reported $(a=0.90)$ and a 1factor structure with coefficients above 0.35 on all items (Dum, Pickren, Sobell, \& Sobell, 2008).

Anxiety

Anxiety was measured with the Spielberger State-Trait Anxiety Inventory (STAI) which consists of two 20-item scales: state and trait (Spielberger, 1983). The internal consistency of the STAI is high ( $a=$ $0.86-0.95)$. The tool has good validity (Spielberger, 1983) and has been used in persons on methadone (Darke, Swift, \& Hall, 1994).

Continued drug use and drug use consequences

Study outcome measures included continued drug use and consequences of drug use. MMT includes random urine testing one to several times per week and this information was used as a measure of continued drug use. All urine tests for illicit drugs that subjects completed over the month prior to study enrollment were collected. Test results indicated the presence or absence in the urine of specific illicit drugs including heroin, cocaine, methadone, opiates, barbiturates, alcohol, benzodiazepines, amphetamines, and marijuana. A single positive test in the prior 30 days was considered evidence of continued drug use.

Consequences of continued drug use were measured using the recent version of the 50-item Inventory of Drug Use Consequences (InDUC, version 2R3). This questionnaire assessed negative consequences of continued drug use over the prior 30 days (Tonigan \&

Western Journal of Nursing Research, Vol. 35, No. 6 (July 2013): pg. 795-814. DOI. This article is @ SAGE Publications and permission has been granted for this version to appear in e-Publications@Marquette. SAGE Publications does not grant permission for this article to be further copied/distributed or hosted elsewhere without the express permission from SAGE Publications. 
Miller, 2002). Individual items asked the frequency of occurrence of the particular negative consequence with higher scores indicating more negative consequences. Frequencies ranged from never to daily or almost daily. Items on the InDUC include alcohol or drugs harming the ability to be a good parent (interpersonal), spiritual or moral life (intrapersonal), work behavior (social responsibility), and proper eating (physical), and increasing risk taking (impulse control). The total score ranges from 0-150. Internal consistency has been reported at 0.82-0.94 (Conner, et al., 2009), with good test-retest reliability on four subscales (0.68-0.92) and poor on the fifth subscale (intrapersonal, 0.33) (Tonigan \& Miller, 2002).

\section{Procedures}

After receiving Institutional Review Board and clinic approval, the study was advertised by posting a flyer in the clinic lobby and the primary investigator (PI) handed out flyers to clinic patients. The majority of the clinic population was available during the recruitment period as MMT includes daily doses of oral liquid methadone and weekly group and individual counseling sessions at the clinic. Those expressing interest met privately with the PI, reviewed the consent form, and had questions answered. Throughout the consenting and data collection process, participants were given repeated opportunities to withdraw from the study.

After the study participants gave written consent, they were logged on to a computer by the PI and given instructions and allowed to ask questions on the radio buttons and moving to the next screen. Participants then independently completed self-administered online study questionnaires for spiritual well-being, religiosity, depression, anxiety, and drug use consequences. The data from the questionnaires was collected using an online data repository. Most participants took 15-30 minutes to complete the five questionnaires. After the participant completed the questionnaires, the PI performed a chart review to gather demographic data and urine test results. Data collection was completed over a six month time period in order to obtain a sufficient sample size. 
NOT THE PUBLISHED VERSION; this is the author's final, peer-reviewed manuscript. The published version may be accessed by following the link in the citation at the bottom of the page.

\section{Data Analysis}

SPSS 17.0 (SPSS, 2009) was used for all analyses. Cronbach's alpha reliability estimates were calculated for the SWBS, RBB, PH9, and STAI. Descriptive statistics (mean, standard deviation, and range) were utilized to characterize spiritual well-being (SWBS) and religiosity (RBB) for research question one (Table 2). One-sample T-test was used to determine SWBS score differences between study participants and reference groups of persons with alcohol or drug addiction that were found in the literature.

For research question two examining relationships of study variables, a correlation matrix (Pearson's $r$ ) was computed were examining the relationships between the summated scores for the depression (PHQ-9), drug use consequences measure (InDUC), and the subscales of the STAI (state and trait), the spiritual well-being subscales (SWBS-EWB and and SWBS-RWB), and the religiosity subscales (RBB-GC and RBB-FP).

Multiple regression analysis was completed to examine research question three to determine whether spirituality (SWBS), religiosity (RBB), depression (PHQ-9), and anxiety (STAI) could predict negative consequences (InDUC). The analysis included four predictor variables, SWBS, RBB, PHQ-9, and STAI with the InDUC as a dependent variable. Logistic regression analysis was used with the same predictor variables to examine the association of urine test to spiritual well-being, religiosity, depression, and anxiety.

\section{Results}

One-hundred and eleven study participants were recruited with 108 completing all the study questionnaires. Of the three participants who did not provide a complete set of study questionnaires, one became fatigued, one did not complete due to time constraints, and one withdrew before completing the last questionnaire due to emotional stress and the desire to discuss her situation with her counselor instead. This sample represented about one-fourth of the clinic census during the study period.

The majority of the participants were white, non-Hispanic, had a high school or equivalent education, and $50 \%$ were male (Table 3 ). Women (mean age 32.4 ) were significantly younger than men (mean

Western Journal of Nursing Research, Vol. 35, No. 6 (July 2013): pg. 795-814. DOI. This article is @ SAGE Publications and permission has been granted for this version to appear in e-Publications@Marquette. SAGE Publications does not grant permission for this article to be further copied/distributed or hosted elsewhere without the express permission from SAGE Publications. 
NOT THE PUBLISHED VERSION; this is the author's final, peer-reviewed manuscript. The published version may be accessed by following the link in the citation at the bottom of the page.

age 37.2) $[\mathrm{t}(106)=-2.193, \mathrm{p}=0.03]$. Most were unemployed at the time of admission to MMT. The study participants had been undergoing MMT for an average of 3.1 years. Many (30\%) had not been treated for drug addiction in the past, however, 33\% declared one prior episode and $23 \%$ declared two prior episodes of addiction treatment. Heroin was the most common drug of choice, followed by prescription opioids, such as oxycodone and hydrocodone. Over $70 \%$ of the sample reported no alcohol use when entering MMT and the majority of the rest drank less than once a week.

Study scales were tested for reliability in this study sample. Cronbach's alpha was adequate for each of the study instruments: SWBS: 0.90 for the total scale, with 0.83 for the EWB and 0.92 for the RWB subscales; RBB: 0.89 , with 0.78 for the GC subscale and 0.86 for the FP subscale; PHQ-9: 0.88; STAI: 0.96 for the total scale, with 0.95 for the State subscale and 0.94 for the Trait subscale; and INDUC: 0.97.

\section{Spiritual Well-Being and Religiosity}

Spiritual history was completed upon clinic admission in 90 patients. The majority indicated belief in a higher power $(88 \%)$ and that their spiritual beliefs would impact their treatment (62\%). Only $24 \%$ indicated they attended formal religious or spiritual practices, $37 \%$ indicated formal practices were a significant part of their life, and $58 \%$ indicated they meditated or prayed regularly. Some of the reasons given for not attending church were the drug use changed their interest level, consumed their time, or made them feel guilty. Nine people noted a positive effect from spiritual and religious practices such as praying more often, turning to God because of their drug use, and feeling more spiritual.

To determine if the MMT group was similar to other groups with addiction, the SWBS mean (86.7) was compared to three similar groups of persons with addiction found in the literature (Brome, et al., 2000; Piderman, 2005; States, 2001). A one-sample t-test was used to determine if the SWBS of the current sample differed from the reference groups. Seven groups taken from the three studies had an overall SWBS mean score of 85.7 . The mean score of 86.7 for this study is not significantly different from that reported in the literature $\left(t_{(107)}=0.624, p=0.534\right)$.

Western Journal of Nursing Research, Vol. 35, No. 6 (July 2013): pg. 795-814. DOI. This article is @ SAGE Publications and permission has been granted for this version to appear in e-Publications@Marquette. SAGE Publications does not grant permission for this article to be further copied/distributed or hosted elsewhere without the express permission from SAGE Publications. 
The Religious Background and Behaviors Questionnaire (RBB) demonstrated a mean of 23.7 in this sample. The overwhelming majority of participants described themselves as spiritual or religious $(86.1 \%)$, that is, they believed in a sacred being or supreme reality regardless of whether they practiced religion. The scores on the God Consciousness subscale averaged 13.1 out of a possible 18 . The scores on the Formal Practices subscale averaged 10.6 out of a possible 28. Fifty-one percent of the sample endorsed that they attended religious services regularly in the past but did not do so now.

\section{Associations Among Spiritual Well-Being, Religiosity, Depression, Anxiety and Drug Use Consequences}

A correlation matrix described the relationships between the SWBS, RBB, PHQ-9, STAI, and InDUC (Table 4). Spiritual well-being was found to have a moderate inverse significant correlation to both the depression $(r=-0.47, p<0.01)$ and anxiety $(r=-0.46, P<0.01)$ measures. The spiritual well-being subscales both inversely correlated to depression, the SWBS-EWB $(r=-0.61, p<0.01)$ and the SWBS-RWB $(r=-0.22, p<0.05)$, but only the SWBS-EWB inversely correlated with anxiety $(r=0.67, P<0.01)$. Religiosity was not found to correlate with depression and anxiety. However, the formal practices subscale inversely correlated with both depression $(r=-0.23, p<0.05)$ and anxiety $(r=-0.21, p<0.05)$ depression and anxiety. The SWBS did not correlate with the negative drug use consequences (InDUC), but the SWBS-EWB $(r=-0.22, p<0.05)$ did correlate significantly. Depression $(r=0.39, p<0.01)$ and anxiety $(r=0.40, p<0.01)$ both moderately significantly correlated with negative drug use consequences.

\section{Spiritual Well-Being, Religiosity, Depression, And Anxiety as Predictors of Continued Drug Use And Drug Use Consequences}

The results of the multiple regression analysis of negative drug use consequences (InDUC) on spiritual well-being (SWBS), religiosity (RBB), depression (STAI), and anxiety (PHQ-9) are presented in Table 5 . The four predictor variables were entered simultaneously into the regression equations. The resultant model (Table 5-Model 1) was statistically significant with the predictor variables accounting for $20.3 \%$ of the variance in the $\operatorname{InDUC}\left(\mathrm{R}^{2}=0.203\left[A \mathrm{R}^{2}=.17\right]\right.$;

Western Journal of Nursing Research, Vol. 35, No. 6 (July 2013): pg. 795-814. DOI. This article is @ SAGE Publications and permission has been granted for this version to appear in e-Publications@ Marquette. SAGE Publications does not grant permission for this article to be further copied/distributed or hosted elsewhere without the express permission from SAGE Publications. 
$F(4,103)=6.57, p<.001)$. The total score on the STAI was the only significant independent predictor.

To address possible collinearity of SWBS and RBB, using backward selection RBB was removed and the model was run with 3 predictor variables (Table 5-Model 2). The three predictor variables of SWBS, STAI and PHQ-9 again accounted for $20.3 \%$ of the variance in the InDUC. The total STAI scale again emerged as was the only significant predictor $(\beta=0.35, t=2.2, p=.03)$.

To assess the predictors of positive urine results, logistic regression analysis was conducted using the predictor variables of SWBS, RBB, PHQ-9, and STAI. Sixty-one participants (57\%) had at least one urine positive for illicit drugs during the month prior to the study. The regression model was not significant $\left(F_{(4,103)}=1.08\right.$ $p=.372)$. The most common illicit drugs found were opiates, benzodiazepines, marijuana, cocaine, propoxyphene, and amphetamines.

\section{Discussion}

The spiritual well-being of this study group was lower than reported in the literature for healthy groups. However, it was not significantly lower when tested against samples of persons with addiction. For example, a group of African-American mothers with an average of two years in substance recovery reported a moderate SWBS (Brome, et al., 2000). This less than healthy score was presumed to be due to a lack of spiritual harmony when struggling with addiction. This study confirms findings in the literature that spiritual well-being in lower in persons with addiction.

Lower spiritual well-being in this study may be related to the continuing use of illicit drugs by participants. The majority of the study participants, despite the long average time in MMT, had at least one urine test indicating use of an illicit drug and were, at best, partially recovered. Recent literature has suggested that MMT should be seen as a recovery program and not an abstinence program as it has been historically viewed (White \& Mojer-Torres, 2010). Continued use of drugs might be considered an expression of a person searching for a spiritual experience. However, one small study did not find this as a reason for continued drug use in MMT (Heinz, et al., 2010).

Western Journal of Nursing Research, Vol. 35, No. 6 (July 2013): pg. 795-814. DOI. This article is @ SAGE Publications and permission has been granted for this version to appear in e-Publications@Marquette. SAGE Publications does not grant permission for this article to be further copied/distributed or hosted elsewhere without the express permission from SAGE Publications. 
NOT THE PUBLISHED VERSION; this is the author's final, peer-reviewed manuscript. The published version may be accessed by following the link in the citation at the bottom of the page.

Spiritual well-being is not a focus in many MMT programs which contrasts to AA 12-step programs in which spirituality is a major part of the treatment program. The MMT clinic policy discouraged counselors from discussing spiritual topics unless initiated by the client. This lack of attention to spiritual well-being, and therefore a lack of a comprehensive focus on the person, could be a limiting factor in recovery.

Spirituality and religiosity was not associated with drug use consequences or continued drug use in this study causing questions about including spiritual interventions in treatment. Recent research suggests that spiritual counseling is not effective in treatment. Two clinical trials of newly detoxified patients compared usual care to persons provided a spiritual director (Miller et al., 2008). The trials found no difference in drug use outcomes at four months between the two groups. These trials suggested that spiritual interventions do not make a difference. However, caution should be used in interpreting the results as the interventions in this trials may not have been timed appropriately or have been long enough to make a difference. Also, the spiritual interventions were by spiritual directors not from the normal patient community. While spiritual counseling and support may not be effective during inpatitne treamtne, it may have some utility during the later stages of recovery during MMT. White and MojerTorres (2010) suggest that addiction should be considered a chronic condition and treated with attention to family, social and spiritual recovery within the community. Perhaps interventions as part of a person's faith community would make a difference.

The religiosity of the MMT group is difficult to assess as no comparison means are reported in the literature. However, the participants thought about God frequently and had participated in religious activities in the past, though current levels of participation were lower. The participants believed in God or a higher power and prayed frequently, but were not regularly participating in formal practices. Substance use may interfere with formal practices that sustain spirituality.

The inverse correlations between spiritual well-being and depression and anxiety are congruent with a study of older patients with advanced cancer in the United Kingdom (McCoubrie and Davies, 2006). Similar to this study, cancer patient's scores on the SWBS and

Western Journal of Nursing Research, Vol. 35, No. 6 (July 2013): pg. 795-814. DOI. This article is @ SAGE Publications and permission has been granted for this version to appear in e-Publications@Marquette. SAGE Publications does not grant permission for this article to be further copied/distributed or hosted elsewhere without the express permission from SAGE Publications. 
the SWBS-EWB subscale negatively correlated to both depression and anxiety. This negative correlation may be because the SWBS-EWB subscale includes measures of psychological well-being (Koenig, 2008) and thus compares positive psychological measures to anxiety and depression. The SWBS-RWB subscale did not correlate to depression or anxiety in the cancer group. In the current study the SWBS-RWB subscale inversely correlated with depression, but not anxiety. Depression may keep people from religious practices more than anxiety, according to the SWBS.

However, the findings are different with the RBB which did not correlate to anxiety or depression. When the RBB-FP subscale was examined, it did correlate inversely to both anxiety and depression. The RBB- FP findings are congruent with studies showing that religiosity and depression are inversely correlated (Koenig, 2009). The relationship between formal religious practices and anxiety is not supported in the literature. One reason for the lack of support for an inverse relationship may be that anxiety itself may spur more religious activities, such as praying (Koenig, McCollough, \& Larson, 2001).

Spiritual well-being and religiosity were not found to be associated with negative drug use consequences. Anxiety was associated with drug use consequences in the regression model, but not depression. As evident in the correlation matrix, anxiety and depression are highly correlated and therefore collinear in their relationship with drug use consequences, with anxiety being the stronger predictor variable. The more depression or anxiety the person has, the more likely the person will have higher scores of negative consequences. However, overall, the regression model accounts for a substantial (20\%) portion of the variance in drug use consequences. Given the complexity of people as dynamic systems of interacting variables (Neuman \& Fawcett, 2002) and the many variables involved in negative life effects associated with addiction, a focus on anxiety reduction within addiction treatment is warranted. While spiritual well-being was not independently associated with drug use consequences, the moderately high correlation of emotional wellbeing dimension of spiritual well-being with anxiety suggests a trajectory of potential influence from spiritual well-being to lower anxiety to lower drug use consequences. Future research is needed to determine if spiritual well-being interventions can impact anxiety permission has been granted for this version to appear in e-Publications@Marquette. SAGE Publications does not grant permission for this article to be further copied/distributed or hosted elsewhere without the express permission from SAGE Publications. 
during MMT that can then have a positive influence on drug use consequences.

Spiritual well-being, religiosity, depression, and anxiety were not found to be associated with urine that was positive for illicit drugs. This could be due to the complex nature of drug use and factors leading to illicit drug use despite being in MMT or insufficient sample size to detect smaller than a two-fold odds ratio. Only one of urine test results and depression was located, which was an intervention study of methadone maintenance patients who used heroin plus cocaine and were new to treatment. The study found depression correlated with positive cocaine urine screens at the end of 25 weeks (Ghitza, Epstein and Preston, 2007). This study did not support these findings.

The current study has limited generalizability due to the relatively small sample size and the cross-sectional design with convenience sampling methods. This sample had characteristics specific to the location of the clinic that are not generalizable to other populations, such as being predominantly white, urban, and young. Computer administration of questionnaires also is a limitation as some may have not participated due to concerns regarding computer skills. The study tools themselves had some limitations. The measures of spiritual well-being and religiosity may not be refined enough to measure these complex multi-dimensional topics. The SWBS has questions that may measure psychological well-being and thus are not separate concepts when comparing against anxiety and depression. The RBB has no comparison groups in the literature. The STAI used words such as "keenly" that may not be meaningful to younger participants. Another limitation was the use of the admission questionnaire for drug use and spiritual history. Patients may not have been truthful on admission to the clinic. For example, the amount of alcohol used at study admission was remarkably low and may have been affected by patients not reporting accurately due to social desirability or other factors. Also, attention to frequency and route of use may have been helpful to determine factors about continued drug use.

This study demonstrated relationships among the study variables in opioid abusers but these relationships need further exploration. Questions remain regarding what changes in spirituality permission has been granted for this version to appear in e-Publications@Marquette. SAGE Publications does not grant permission for this article to be further copied/distributed or hosted elsewhere without the express permission from SAGE Publications. 
and religiosity occur during treatment. Understanding how the spirituality of the care provider and the patient relate and how to match providers would also be beneficial. More knowledge of spirituality is needed to aid in recovery and prevent relapse of patients.

This study was the first to examine the spirituality, religiosity, depression, and anxiety together in persons undergoing methadone therapy for opioid abuse. The majority of the sample described themselves as spiritual or religious. The study was framed using Neuman's model and examined the interrelationships of the person variables. Correlations were found among spiritual well-being, religiosity, depression, anxiety, and negative drug use consequences. The negative consequences of addiction are many and continue to add to the poor health of the individual, family, and society at large. Through understanding these relationships, interventions can begin to be developed to strengthen one variable of the person with the expectation that it also will strengthen other variables of the human person.

Because addiction is prevalent in society and contributes to other health problems, nurses often encounter addicted patients. Knowing more about these patients can help nurses deliver better care. Spirituality is a factor in maintaining health and well-being and is an important resource for nurses to utilize in patient care. Continued knowledge development is needed to understand spirituality and religiosity in addiction. Knowledge of the person with addiction including the complexity of spirituality and religiosity in relation to anxiety and depression may be useful to nurses in treating many patients. Nurses need to understand spirituality and how to give spiritual care and to be comfortable when doing so.

This current study noted less consistency in charting spiritual history than the other portions assessed in the intake assessment. This lack attention to spiritual history could be because the counselors are instructed not to probe spiritual or religious topics if the client does not offer answers to the questions. Discomfort with the topic by either the patient or the counselor, or a lack of importance attributed to a spiritual history by the addiction counselors may contribute to avoidance of spiritual counseling. Counselors and nurses need to understand that spirituality and religiosity are important to the permission has been granted for this version to appear in e-Publications@Marquette. SAGE Publications does not grant permission for this article to be further copied/distributed or hosted elsewhere without the express permission from SAGE Publications. 
majority of persons with addiction. Addressing the spirituality and religiosity needs of persons in addition recovery enhances holistic care and will promote the well-being of the person with addiction. Future research may be able to document beneficial treatment outcomes.

This study demonstrated relationships among opioid abusers that need further exploration. Longitudinal interventional studies using spiritual techniques such as being present and listening to a patient, prayer, or meditation in an attempt to affect spirituality and help the person towards transcendence would be useful. Studies exploring how to match providers to patients to most effectively help the person grow spiritually during addiction could be useful. Finally, studies with a recovery orientation in a community, such as a faith community, would be more naturalistic and perhaps more beneficial.

Table 1. Theoretical Model, Study Concepts, and Variables

\begin{tabular}{|c|c|c|c|c|}
\hline $\begin{array}{l}\text { Neuman System's } \\
\text { Model: Person as } \\
\text { dynamic system }\end{array}$ & Spiritual & Psychological & $\begin{array}{l}\text { Sociocultural/ } \\
\text { developmental }\end{array}$ & Physiological \\
\hline Study concepts & $\begin{array}{l}\text { Spirituality } \\
\text { Religiosity }\end{array}$ & $\begin{array}{l}\text { Depression } \\
\text { Anxiety }\end{array}$ & $\begin{array}{l}\text { Drug Use } \\
\text { Consequences }\end{array}$ & $\begin{array}{l}\text { Continuing } \\
\text { Drug Use }\end{array}$ \\
\hline Study variables & $\begin{array}{l}\text { Spiritual Well } \\
\text { Being Scale } \\
\text { Religious } \\
\text { Background } \\
\text { and Behavior } \\
\text { Questionnaire }\end{array}$ & $\begin{array}{l}\text { Patient Health } \\
\text { Questionnaire -9 } \\
\text { State-Trait } \\
\text { Anxiety Scale }\end{array}$ & $\begin{array}{l}\text { Inventory of } \\
\text { Drug Use } \\
\text { Consequences }\end{array}$ & $\begin{array}{l}\text { Illicit drug use } \\
\text { in prior } 30 \\
\text { days per urine } \\
\text { test }\end{array}$ \\
\hline
\end{tabular}

Western Journal of Nursing Research, Vol. 35, No. 6 (July 2013): pg. 795-814. DOI. This article is @ SAGE Publications and permission has been granted for this version to appear in e-Publications@Marquette. SAGE Publications does not grant permission for this article to be further copied/distributed or hosted elsewhere without the express permission from SAGE Publications. 
NOT THE PUBLISHED VERSION; this is the author's final, peer-reviewed manuscript. The published version may be accessed by following the link in the citation at the bottom of the page.

Table 2. Scale Scores and Selected Sample Characteristics

\begin{tabular}{lll}
\hline Variables & $\begin{array}{l}\text { Mean (SD) } \\
(n=108)\end{array}$ & Range \\
\hline Age (years) & $34.8(11.5)$ & $21-65$ \\
Length of time in MMT(years) & $3.1(4.53)$ & $0-28$ \\
Spiritual well-being scale (SWBS) & $86.7(16.41)$ & $51-120$ \\
Existential well-being(EWB) & $41.4(8.76)$ & $20-60$ \\
Religious well-being (RWB) & $45.3(10.58)$ & $10-60$ \\
Religious Background and Behavior (RBB) & $23.7(9.8)$ & $0-46$ \\
God Consciousness (GC) & $13.1(4.07)$ & $0-18$ \\
Formal Practices (FP) & $10.6(6.69)$ & $0-28$ \\
Patient Health Questionnaire 9-item depression & $10.6(6.90)$ & $0-26$ \\
module (PHQ-9) & & \\
State-Trait Anxiety Inventory (STAI) & $92.1(24.0)$ & $43-156$ \\
Inventory of Drug Use Consequences (InDUC) & $35.0(28.78)$ & $0-107$ \\
& & \\
\hline
\end{tabular}

Western Journal of Nursing Research, Vol. 35, No. 6 (July 2013): pg. 795-814. DOI. This article is @ SAGE Publications and permission has been granted for this version to appear in e-Publications@Marquette. SAGE Publications does not grant permission for this article to be further copied/distributed or hosted elsewhere without the express permission from SAGE Publications. 
NOT THE PUBLISHED VERSION; this is the author's final, peer-reviewed manuscript. The published version may be accessed by following the link in the citation at the bottom of the page.

Table 3. Sample Characteristics

\begin{tabular}{|c|c|c|}
\hline & Number & Percent \\
\hline \multicolumn{3}{|l|}{ Race } \\
\hline White & 96 & 90 \\
\hline African-American & 6 & 6 \\
\hline Native American & 5 & 5 \\
\hline Other & 1 & 1 \\
\hline \multicolumn{3}{|l|}{ Ethnicity } \\
\hline Hispanic & 12 & 11 \\
\hline Non-Hispanic & 96 & 89 \\
\hline \multicolumn{3}{|l|}{ Sex } \\
\hline Female & 54 & 50 \\
\hline Male & 54 & 50 \\
\hline \multicolumn{3}{|l|}{ Education } \\
\hline Less than H.S. & 27 & 25 \\
\hline High School & 69 & 64 \\
\hline$<4$ years College & 4 & 4 \\
\hline$\geq 4$ years College & 3 & 3 \\
\hline Missing Data & 5 & 5 \\
\hline \multicolumn{3}{|l|}{ Primary Drug of Addiction } \\
\hline Heroin & 46 & 43 \\
\hline Prescription opiates & 36 & 33 \\
\hline Illegal Methadone & 5 & 5 \\
\hline All opiates & 17 & 16 \\
\hline Missing Data & 4 & 4 \\
\hline \multicolumn{3}{|l|}{ Years in MMT } \\
\hline$<1$ & 40 & 37 \\
\hline $1-2$ & 19 & 17 \\
\hline $2-3$ & 13 & 12 \\
\hline $3-5$ & 13 & 12 \\
\hline 5 or more & 22 & 20 \\
\hline \multicolumn{3}{|l|}{ Religious Background } \\
\hline Spiritual & 48 & 44 \\
\hline Religious & 45 & 42 \\
\hline Unsure & 11 & 10 \\
\hline Negative for illicit drugs & 47 & 44 \\
\hline
\end{tabular}

Western Journal of Nursing Research, Vol. 35, No. 6 (July 2013): pg. 795-814. DOI. This article is @ SAGE Publications and permission has been granted for this version to appear in e-Publications@Marquette. SAGE Publications does not grant permission for this article to be further copied/distributed or hosted elsewhere without the express permission from SAGE Publications. 
NOT THE PUBLISHED VERSION; this is the author's final, peer-reviewed manuscript. The published version may be accessed by following the link in the citation at the bottom of the page.

Table 4. Correlation Matrix for Spiritual Well-Being, Religiosity, Depression, Anxiety and Drug Use Consequences (Pearson's r correlations)

\begin{tabular}{|c|c|c|c|c|c|c|c|c|}
\hline & RBB & $\mathrm{GC}$ & FP & PHQ-9 & STAI & State & Trait & InDUC \\
\hline SWBS & $0.60 * *$ & $0.57 * *$ & $0.53 * *$ & $-0.47 * *$ & $-0.46^{* * *}$ & $-0.40 * *$ & $-0.46^{* * *}$ & -0.07 \\
\hline EWB & $0.33 * *$ & $0.23^{*}$ & $0.34 * *$ & $-0.61 * *$ & $-0.67 * *$ & $-0.58 * *$ & $-0.67 * *$ & $-0.22 *$ \\
\hline RWB & $0.65^{* *}$ & $0.69 * *$ & $0.54 * *$ & $-0.22^{*}$ & -0.17 & -0.14 & -0.17 & 0.07 \\
\hline RBB & & & & -0.16 & -0.12 & -0.10 & -0.13 & 0.03 \\
\hline $\mathrm{GC}$ & & & & 0.01 & 0.06 & 0.04 & 0.06 & 0.11 \\
\hline FP & & & & $-0.23^{*}$ & $-0.21^{*}$ & -0.17 & $-0.23^{*}$ & -0.03 \\
\hline PHQ-9 & & & & & $0.75 * *$ & $0.61 * *$ & $0.79 * *$ & $0.39 * *$ \\
\hline STAI & & & & & & & & $0.40 * *$ \\
\hline State & & & & & & & & $0.38 * *$ \\
\hline Trait & & & & & & & & $0.36^{* * *}$ \\
\hline
\end{tabular}

SWBS-Spiritual Well-Being Scale; EWB-Existential Well-Being Subscale; RWB-Religious Well-Being; RBB-Religious Background and Behavior Scale; GC-God Consciousness subscale; FP-Formal Practices subscale; PHQ-9-Patient Health Questionnaire 9-item Depression Module; STAI-State-Trait Anxiety Inventory; State-State Anxiety Scale; Trait-Trait Anxiety Scale; InDUC-Inventory of Drug Use Consequences

$* p<0.05$ (2-tailed)

$* * \mathrm{p}<0.01$ (2-tailed)

Western Journal of Nursing Research, Vol. 35, No. 6 (July 2013): pg. 795-814. DOI. This article is @ SAGE Publications and permission has been granted for this version to appear in e-Publications@Marquette. SAGE Publications does not grant permission for this article to be further copied/distributed or hosted elsewhere without the express permission from SAGE Publications. 
NOT THE PUBLISHED VERSION; this is the author's final, peer-reviewed manuscript. The published version may be accessed by following the link in the citation at the bottom of the page.

Table 5. Predictors of Negative Drug Use Consequences

\begin{tabular}{|c|c|c|c|c|c|c|}
\hline \multirow{2}{*}{$\begin{array}{l}\text { Predictor } \\
\text { Variables }\end{array}$} & \multirow{2}{*}{$\begin{array}{c}\text { Model } \\
\text { Statistics }\end{array}$} & \multicolumn{5}{|c|}{ Variable Statistics } \\
\hline & & B & SE B & $\begin{array}{c}\text { Standard- } \\
\text { ized } \beta\end{array}$ & $\mathrm{t}$ & $\mathrm{p}$ \\
\hline \multicolumn{7}{|l|}{ Model 1} \\
\hline \multirow{4}{*}{$\begin{array}{ll}\text { a. } & \text { SWBS } \\
\text { b. } & \text { RBB } \\
\text { c. } & \text { STAI } \\
\text { d. } & \text { PHQ-9 }\end{array}$} & $F_{(4,103)}=6.57$ & 0.34 & 0.22 & 0.19 & 1.51 & 0.14 \\
\hline & $\mathrm{p}=<0.001$ & -0.39 & 0.33 & -0.01 & -0.12 & 0.90 \\
\hline & $\mathrm{R}^{2}=0.203$ & 0.36 & 0.16 & 0.30 & 2.18 & 0.03 \\
\hline & & 1.07 & 0.56 & 0.26 & 1.90 & 0.06 \\
\hline \multicolumn{7}{|l|}{ Model 2} \\
\hline \multirow{3}{*}{$\begin{array}{ll}\text { a. SWBS } \\
\text { b. STAI } \\
\text { c. }\end{array}$} & $F_{(4,103)}=8.84$ & 0.32 & 0.18 & 0.18 & 1.81 & 0.07 \\
\hline & $\mathrm{p}=<0.001$ & 0.35 & 0.16 & 0.30 & 2.20 & 0.03 \\
\hline & $\mathrm{R}^{2}=0.203$ & 1.07 & 0.56 & 0.26 & 1.91 & 0.06 \\
\hline
\end{tabular}

SWBS-Spiritual Well-Being Scale; RBB-Religious Background and Behavior Scale; STAI-State-Trait Anxiety Scale; PHQ-9- Patient Health Questionnaire 9-item Depression Module

\section{References}

Brizer, D. A. (1993). Religiosity and Drug abuse among psychiatric inpatients. American Journal of Drug and Alcohol Abuse, 19(3), 337-345.

Brome, D. R., Owens, M. D., Allen, K., \& Vevaina, T. (2000). An examination of spirituality among African American women in recovery from substance abuse. Journal of Black Psychology, 26(4), 470-486.

Bufford, R. K., Paloutzian, R. F., \& Ellison, C. W. (1991). Norms for the spiritual well-being scale. Journal of Psychology and Theology, 19(1), 56-70.

Center for Substance Abuse Treatment. (2005). Medication-assisted treatment for opioid addiction in opioid treatment programs. Treatment Improvement Protocol (TIP) Series 43. DHHS Publication No. (SMA) 05-4048. Rockville, MD: Substance Abuse and Mental Health Services Administration.

Western Journal of Nursing Research, Vol. 35, No. 6 (July 2013): pg. 795-814. DOI. This article is @ SAGE Publications and permission has been granted for this version to appear in e-Publications@Marquette. SAGE Publications does not grant permission for this article to be further copied/distributed or hosted elsewhere without the express permission from SAGE Publications. 
Conner, K. R., Ross, M. E., Baciewicz, G., Sworts, L. M., \& Meldrum, S. C. (2009). Reliability of the lifetime inventory of drug use consequences (INDUC) in methadone maintenance patients. Journal of Psychoactive Drugs, 41(1), 93-98.

Connors, G. J., Tonnigan, J. S., \& Miller, W. R. (1996). A measure of religious background and behavior for use in behavior change research. Psychology of Addictive Behaviors, 10(2), 90-96.

Darke, S., Swift, W., \& Hall, W. (1994). Prevalence, severity and correlates of psychological morbidity among methadone maintenanace clients. Addiction, 89, 211-217.

Dum, M., Pickren, J., Sobell, L. C., \& Sobell, M. B. (2008). Comparing the BDI-II and the PHQ-9 with outpatient substance abusers. Addictive Behaviors, 33, 381-387.

Ellison, C. W. (1983). Spiritual well-being: Conceptualization and measurement. Journal of Psychology and Theology, 11(4), 330-340.

Ellison, C. W., \& Smith, J. (1991). Toward an integrative measure of health and well-being. Journal of Psychology and Theology, 19(1), 35-48.

Faul, F., Erdfelder, E., Lang, A.-G., \& Buchner, A. (2007). G*Power 3: A flexible statistical power analysis program for the social, behavioral, and biomedical sciences. . Behavior Research Methods, 39, 175-191.

Fehring, R. J., Miller, J. M., \& Shaw, C. (1997). Spiritual well-being, religiosity, hope, depression, and other mood states in elderly people coping with cancer. Oncology Nursing Forum, 24(4), 663-671.

Ghitza, U. E., Epstein, D. H., \& Preston, K. L. (2007). Psychosocial functioning and cocaine use during treatment: Strength of relationship depends on type of urine-testing method. Drug and Alcohol Dependence, 91(2), 169-177.

Green, L. L., Fullilove, M. T., \& Fullilove, R. E. (1998). Stories of spiritual awakening: The nature of spirituality in recovery. Journal of Substance Abuse Treatment, 15, 325-331.

Hartz, G. W. (2005). Spirituality and Mental Health: Clinical Applications. Binghamton, NY: Hayworth Pastoral Press.

Heinz, A. J., Disney, E. R., Epstein, D. H., Glezen, L. A., Clark, P. I., \& Preston, K. L. (2010). A Focus-Group Study on Spirituality and Substance-User Treatment. Substance Use \& Misuse, 45(1/2), 134153. doi: $10.3109 / 10826080903035130$

Western Journal of Nursing Research, Vol. 35, No. 6 (July 2013): pg. 795-814. DOI. This article is (C SAGE Publications and permission has been granted for this version to appear in e-Publications@Marquette. SAGE Publications does not grant permission for this article to be further copied/distributed or hosted elsewhere without the express permission from SAGE Publications. 
NOT THE PUBLISHED VERSION; this is the author's final, peer-reviewed manuscript. The published version may be accessed by following the link in the citation at the bottom of the page.

Hill, P. C., \& Hood Jr., R. W. (Eds.). (1999). Measures of Religiosity. Birmingham, AB: Religious Education Press.

Koenig, H. G. (2008). Concerns about measuring "spirituality" in research. The Journal of Nervous and Mental Disease, 196(5), 349-355.

Koenig, H. G. (2009). Research on religion, spirituality, and mental health: A review. Canadian Journal of Psychiatry, 54(5), 283-291.

Koenig, H. G., McCullough, M. E., \& Larson, D. B. (2001). Handbook of Religion and Health. New York: Oxford University Press.

Kroenke, K., Spitzer, R. L., \& Williams, J. B. (2001). Validity of a brief depression severity measure. Journal of General Internal Medicine, 16, 606-613.

McCoubrie, R. C., \& Davies, A. N. (2006). Is there a correlation between spirituality and anxiety and depression in patients with advanced cancer? Support Care Cancer, 14, 379-385.

Miller, W. R., \& Bogenschutz, M. P. (2007). Spirituality and Addiction. Southern Medical Journal, 100(4), 433-436 doi: 10.1097/SMJ.0b013e3180316fbf

Miller, W.R., Forcehimes, A., O'Leary, M. J. \& LaNoue, M.D. (2008). Spiritual direction in addiction treatment: Two clinical trials. Journal of Substance Abuse Treatment, 35, 434-442.

National Drug Intelligence Center (2011). The Economic Impact of Illicit Drug Use on American Society. Washington, D. C.: United States Department of Justice Retrieved from http://www.justice.gov/ndic/.

Neuman, B., \& Fawcett, J. (2002). The Neuman Systems Model (4th ed.). Upper Saddle River, New Jersey: Prentice Hall.

O'Brien, M.E. (2011) Spirituality in Nursing: Standing on Holy Ground (4th ed.). Sudbury, MA: Jones \& Bartlett Learning.

Piderman, M. A. K. (2005). Spirituality and abstinence self-efficacy in persons with alcohol dependence. Ph.D. Dissertation, Walden University.

Spielberger, C. D. (1983). State-Trait Anxiety Inventory for Adults: Sampler Set. Palo Alto, CA: Consulting Pschycologists Press.

SPSS, Inc. (2009). SPSS (Version 17.0) [Computer Software]. Chicago: SPSS, Inc.

Western Journal of Nursing Research, Vol. 35, No. 6 (July 2013): pg. 795-814. DOI. This article is @ SAGE Publications and permission has been granted for this version to appear in e-Publications@Marquette. SAGE Publications does not grant permission for this article to be further copied/distributed or hosted elsewhere without the express permission from SAGE Publications. 
NOT THE PUBLISHED VERSION; this is the author's final, peer-reviewed manuscript. The published version may be accessed by following the link in the citation at the bottom of the page.

States, J. A. (2001). Self-efficacy and spirituality in the recovery process from alcohol dependence: A paradox. Ph.D. Dissertation, West Virginia University, Morgantown, West Virginia.

Stimmel, B. (2009). From addiction to abstinence: Maximizing the chances of success. Family Court Review, 47(2), 265-273.

Substance Abuse and Mental Health Services Administration. (2012). Results from the 2010 National Survey on Drug Use and Health: Mental Health Findings. Rockville, MD: Substance Abuse and Mental Health Services Administration.

Tonigan, J. S. (2007). Spirituality and Alcoholics Anonymous. Southern Medical Journal, 100(4), 437-440 410.1097/SMJ.1090b1013e31803171ef.

Tonigan, J. S., \& Miller, W. R. (2002). The inventory of drug use consequences (InDUC): Test-Retest stability and sensitivity to detect change. Psychology of Addictive Behaviors, 16(2), 165-168.

Verthein, U., Degkwitz, P., Haasen, C., \& Krausz, M. (2005). Significance of comorbidity for the long-term course of opiate dependence. European Addiction Research, 11, 15-21.

Warner, M., Chen, L. H., \& Makuc, D. M. (2009). Increase in fatal poisonings involving opioid analgesics in the United States, 1999-2006. NCHS data brief, no 22. Hyattsville, MD: National Center for Health Statistics.

White, W., \& Mojer-Torres, L. (2010). Recovery-oriented methadone maintenance. Chicago, Philadepelphia, Pittsburgh: Great Lakes Addiction Technology Transfer Center, Philadelphia Department of Behavioral Health and Mental Retardation Services, Northeast Addiction Technology Transfer Center.

\section{About the Authors}

Linda B. Piacentine: Marquette University College of Nursing, P.O. Box 1881, Milwaukee, WI 53201, USA.

Email: linda.piacentine@marquette.edu

Western Journal of Nursing Research, Vol. 35, No. 6 (July 2013): pg. 795-814. DOI. This article is @ SAGE Publications and permission has been granted for this version to appear in e-Publications@Marquette. SAGE Publications does not grant permission for this article to be further copied/distributed or hosted elsewhere without the express permission from SAGE Publications. 